\title{
Algebraic Reasoning of Student with Keirsey Personality Type in Solving Mathematical Problem
}

\author{
Intan Fathimah Ahmadah * \\ Department of Mathematics Education, Universitas Negeri Surabaya, Indonesia \\ ${ }^{*}$ Corresponding author: Ketintang Building D1 Surabaya 60231, Indonesia. e-mail addresses: intanahmadah@gmail.com
}

\begin{tabular}{l}
\hline $\mathbf{r} \mathbf{i} \mathbf{i} \mathbf{i} \mathbf{i} \mathbf{0}$ \\
\hline How to cite this article: \\
Ahmadah, I.F. (2020). Algebraic Reasoning Of \\
Student With Keirsey Personality Type In \\
Solving Mathematical Problem. Eduma: \\
Mathematics Education Learning And Teaching, \\
9(2), 42 - 48. \\
doi:http://dx.doi.org/10.24235/eduma.v9i2.7191
\end{tabular}

Article history:

Received: 10 01, 2020

Accepted: 11 09, 2020

Published: 12, 2020

Copyright (C) 2020

EduMa: Mathematics Education Learning and Teaching under the Creative Commons Attribution 4.0 International License.

\begin{abstract}
a b s t $\mathbf{r}$ a c t

ALGEBRAIC REASONING OF STUDENT WITH

KEIRSEY PERSONALITY TYPE IN SOLVING

MATHEMATICAL PROBLEM. Algebraic reasoning is an important skill for students to support in learning mathematics, especially on algebraic topics. This research is aimed at describing students' algebraic reasoning to solve problems based on Keirsey's personality types. This research used qualitative with a descriptive approach and was conducted involving four students who have equal mathematical abilities and the same gender. The selected students represented Keirsey's personality types. The selection of students was carried out through two types of tests, namely the Keirsey Temperament Sorter (KTS) and the Mathematics Ability Test (MAT). The result showed that students with Guardian and Idealist personality types liked to use regular and coherent procedures to solve the problem. Then, students with rational and artisan personality types prefer to use complete explanations. So, teachers can improve students' algebraic reasoning skills by facilitating each student based on their personality type, such as developing learning activities that can include every student's algebraic reasoning ability.
\end{abstract}

\section{Keyword s :}

Algebraic reasoning, Problem-solving, Keirsey Personality Type. 


\section{INTRODUCTION}

The reasoning is an important ability for students to learn mathematics. Arslan et al. (2009) Argued reason is very effective for students' ability to analyze new situations faced in various aspects, make logical assumptions, explain the results of their thoughts, make conclusions and defend these conclusions. The ability to analyze can help students solve a problem and influence the development of their knowledge. But in reality, based on the 2015 TIMSS data on students around the world, the results show that the cognitive dimension at the reasoning level is $25 \%$, which cognitive dimension is the lowest compared to other cognitive dimensions such as knowing and applying (Mullis, 2013)

Reasoning comes from the word "reason" which, according to Kamus Besar Bahasa Indonesia, means activities that allow someone to think logically (KBBI, 2016). This shows that one of the characteristics of reasoning is being able to use logic while thinking. Lithner (2008) Argued that reasoning is the thought adopted to produce statements and reach conclusions on solving problems. Brodie's (2010) statement that reason is a basic skill in mathematics aims to develop thinking, solve problems, or integrate several ideas into a coherent whole. So, it can be concluded that reasoning is an activity that uses logic to produce new statements that come from previous statements that aim to conclude problem-solving.

Algebraic reasoning is an important skill for students since algebraic reasoning can improve students' mathematics and science skills. According to Kaput and Blanton (Indraswari et al., 2018), algebraic reasoning is a type of reasoning used to solve algebraic problems. Algebraic reasoning was process students do to find a pattern for specific mathematical problems or contextual situations, build relationships between quantities and write generalizations through formal representation and symbolically manipulation (Andriani, 2015). Algebraic reasoning is a process of thinking involving the generalization of the generation of experience with numbers and calculations to enrich the idea by using symbols and exploring the concept of patterns and functions (Walle et al., 2011). From these definitions, it can be concluded that algebraic reasoning uses logic to solve the problem by finding patterns from mathematical problems, practice recognizing, and making a generalization.

Table 1

Indicator of algebraic reasoning in Solving Problem

\begin{tabular}{|c|c|}
\hline $\begin{array}{l}\text { Algebraic } \\
\text { Reasoning } \\
\text { Stage }\end{array}$ & Indicator \\
\hline $\begin{array}{l}\text { pattern } \\
\text { seeking }\end{array}$ & $\begin{array}{l}\text { a. Students mention } \\
\text { information that } \\
\text { are known from } \\
\text { the problem given } \\
\text { b. Students represent } \\
\text { things that are } \\
\text { known in the form } \\
\text { of pictures, } \\
\text { diagrams, tables or } \\
\text { symbols } \\
\text { Student identify } \\
\text { the elements of the } \\
\text { pattern compliers } \\
\text { through the help of } \\
\text { pictures, diagrams, } \\
\text { tables, or symbols } \\
\text { created }\end{array}$ \\
\hline $\begin{array}{l}\text { pattern } \\
\text { recognizing }\end{array}$ & $\begin{array}{l}\text { a. Students can make } \\
\text { a conjecture about } \\
\text { things that are } \\
\text { known form the } \\
\text { problem } \\
\text { b. Students can prove } \\
\text { the conjecture they } \\
\text { made }\end{array}$ \\
\hline $\begin{array}{l}\text { pattern } \\
\text { generalization }\end{array}$ & $\begin{array}{l}\text { Students can make } \\
\text { patterns in the form of } \\
\text { equations }\end{array}$ \\
\hline
\end{tabular}

Adapted from Herbert E Brown (1997)

To solve a problem, each personality has different strategies, like choosing the process's effectiveness, selecting alternatives, and techniques that could 
solve the problem (Huitt, 1992). Similarly, (Koruklu, 2015) posits a strong correlation between personality types and problemsolving. From both statements, it could be said that each individual solved the problem in different ways according to their personality types.

Personality is the innate person's inborn nature, which causes the emergence of certain feelings, thoughts, and behaviors (Masriyah \& Firmansyah, 2018). One classification of personality based on one's behavioral outlook is Keirsey's Personality theory. Keirsey personality type refers to its own thoughts, emotions, and behaviors that illustrate the way individuals conform to their environment so that the Keirsey personality type is easy to observe. This is in line with (Dewiyani, 2009) that the differences in each Keirsey personality type's behavior are easily observed. Keirsey (1998) classifies the type of human personality in four types, namely Guardian, Artisan, Rational, and Idealist using Keirsey Temperament Sorter (KTS). This theory showcases how a person gains the energy (extrovert or introvert), how a person obtains information (sensing or intuitive), how a person takes a decision (thinking or feeling) and how the basic style of his life (judging or perceiving).

There has been some research on algebraic reasoning in solving problems and their relationship to learning styles, adversity quotients, and mathematical intelligence. Based on (Indraswari et al., 2018) there were differences in student algebraic reasoning with field dependent and field independent learning styles. Kobandaha \& Fuad (2019) also states that there were differences in student algebraic reasoning with logical-mathematical intelligence with spatial visuals. Aryani et al. (2017) also stated that there were differences in quitter, camper, and climber students' algebraic reasoning in solving problems. However, there has been no research on student algebraic reasoning in solving problems reviewed from personality types. According to (Lutfitasari et al., 2018), students' problem solving skills were also influenced by the personality type. This will undoubtedly benefit teachers in the learning process because each personality type difference is easy to observe (Dewiyani, 2009).

This study identified the influence of personality types in algebraic reasoning and showed differences in strategies that students use in solving problems. However, this research will focus on describing students' algebraic reasoning with Keirsey personality types in solving math problems.

Based on the explanation above, the purpose of this study is to describe the algebraic reasoning of students Keirsey's personality type in solving math problems.

\section{RESEARCH METHOD}

The research used descriptive research with a qualitative approach. This research aimed to describe students' algebraic reasoning in solving mathematical problems in terms of guardian, artisan, idealist, and rational personality type. Participants of this study were $10^{\text {th }}$ grade students of senior high school. In determining the subject of research, the participants were given the Keirsey Temperament Sorter (KTS), which consists of 70 questions adopted from (Keirsey \& Bates, 1984), and Mathematics Ability Test (MAT), which consists 10 questions adapted from the Indonesia national exam question. So it was selected four subjects representing each personality type with equivalent mathematical ability and the same gender.

Furthermore, after the research subject was selected, the Problem Solving Test (PST) was carried out. Research subjects were given a problem and asked to solve it. The researcher also told that the test had no effect on their learning course so that the research subjects could do it in any way they believed. A few days later, interviews were conducted with each research subject. 
Here is the problem was given to each

A toy factory makes toy blocks by combining several cubes. The factory uses a sticker attachment machine to attach the sticker to make the blocks are better. The machine will put a sticker on each surface of the cube that is open and each cube must have a sticker, so that in the $1^{\text {st }}$ block there are 6 stickers and several other arrangements appear in the picture below:

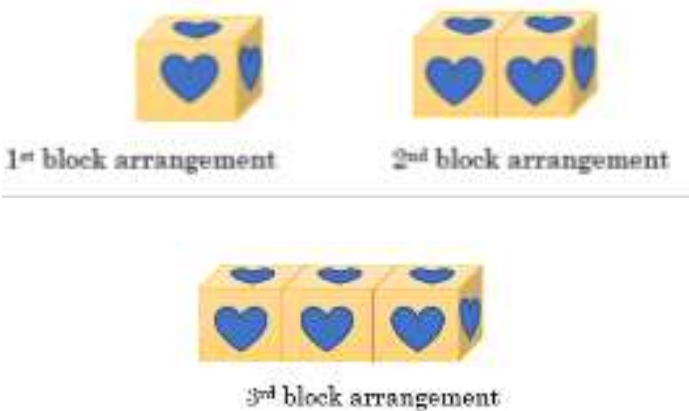

a) How many stickers are needed on the $8^{\text {th }}, 15^{\text {th }}$, and $20^{\text {th }}$ blocks?

b) Write an equation that can help you find the number of $\mathrm{s}$ stickers on the blocks arrangement. Explain your way to get that answer!

students:

Figure 1. The problem Given to each student

\section{RESULT AND DISCUSSION}

The research observed four students namely GS (guardian student), AS (Artisan Student), RS (Rational Student) and IS (idealist Student). Algebraic Reasoning abilities shows by PS (Pattern Seeking), PR (Pattern Recognizing), and PG (Pattern Generalization).

a. Algebraic Reasoning of Guardian Student

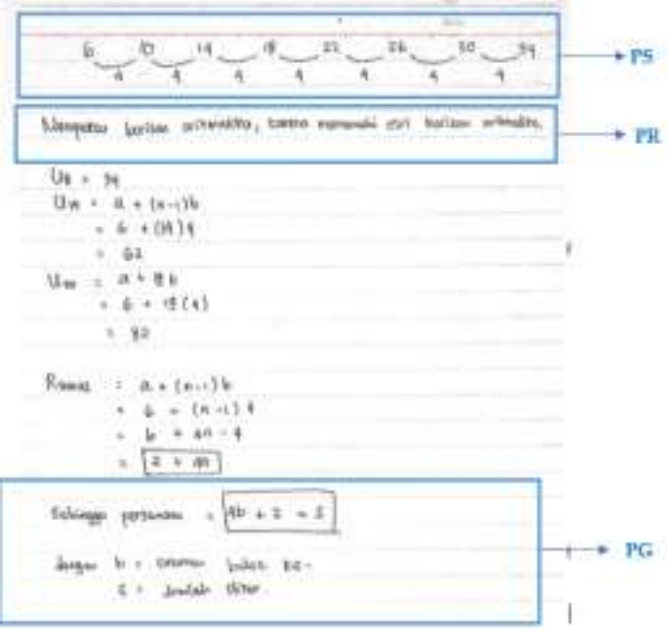

Figure 2. Guardian Student's Answer Sheet

In pattern-seeking, GS created a diagram to show what is known of the given problem. GS identified the number sequence pattern used these diagram. In pattern recognizing, GS indicated or conjectures that the sequence formed is Arithmetic Sequence and problem given can be solved using the formula of Arithmetic Sequence. To identified why GS used arithmetic sequence and found out whether GS proven the conjecture,

R : Why did you use the arithmetic sequence formula? Are you sure that the pattern formed is Arithmetic sequence?

GS : Yes, I'm sure. Because the pattern formed from the number of stickers in each arrangement of Blocks followed arithmetic sequence with the first term is 6 and the different is 4

the researcher did an interview. See the interview transcript in Figure 3.

\section{Figure 3. Interviewed script with GS}

GS has proven the conjecture that has been made. In pattern generalization, GS made the generalization patterns by using formula from arithmetic sequence. This is in accordance with the Guardian personality type described by (Keirsey \& Bates, 1984) that GS likes regular procedure to solve problems. This is accordance with opinion of Kasrina \& Ode (2019) which 
states that the Guardian student likes learning with regular procedures.

b. Algebraic Reasoning of Rational Student

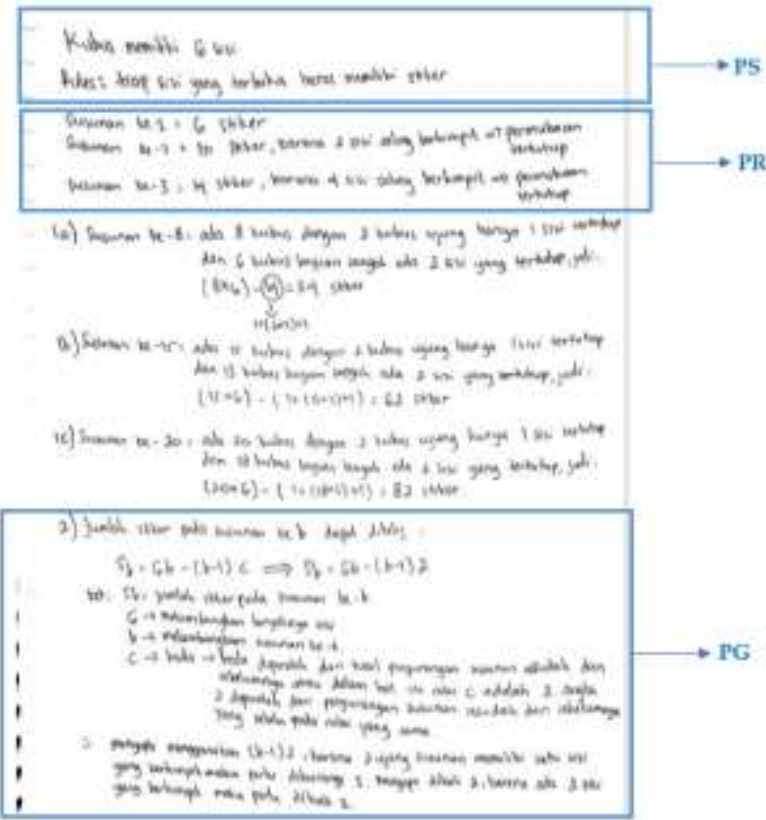

Figure 4. Rational observed in Student's Answer Sheet

In pattern seeking, RS mention what was known from the given problem and explained it in detail. RS mentioned what is known from the number sequence by using long sentence, instead of picture, diagram, tables, or symbols. In pattern recognizing, RS made the conjecture based on the sentences and pattern that have been

\begin{tabular}{|c|c|}
\hline $\mathrm{R}$ & $\begin{array}{l}\text { : Are you sure that the pattern } \\
\text { you made is correct? }\end{array}$ \\
\hline GS & : Of course \\
\hline $\mathrm{R}$ & : Why are you so sure? \\
\hline GS & $\begin{array}{l}\text { I use the logic that, the blocks } \\
\text { are composed of several cubes } \\
\text { that have } 6 \text { sides. For example, in } \\
5^{\text {th }} \text { arrangement, there are } 5 \\
\text { cubes. } 2 \text { cubes in the corner only } \\
\text { have one side closed, so we } \\
\text { substract }(5 \times 6) \text { by } 2 \times 1 \text {. Then, } 3 \\
\text { cubes in the middle have } 2 \text { closed } \\
\text { sides, so we subsract }(5 \times 6) \text { by } \\
3 \times 2 \text {. And the number of sticker } \\
\text { in } 5^{\text {th }} \text { pattern is }(5 \times 6)-(2 \times \\
1)-(3 \times 2) \text {. as well as the next } \\
\text { pattern, the form of the addition } \\
\text { will always become like that, } \\
\text { because the order is same. }\end{array}$ \\
\hline
\end{tabular}

compiled. To find out whether RS proved the conjecture RS had made, an interview was administrated. (see the interview transcript in Figure 5).

Figure 5. Interviewed script with RS

$\mathrm{RS}$ has proven the conjecture that has been made. In pattern generalization, $\mathrm{RS}$ generalized pattern number using the descriptions and pattern RS has created. This follows the Rational personality type described by (Keirsey \& Bates, 1984), who likes to explain it based on logic. The result was also pursuing research from (Solichah \& Sulaiman, 2019), who states that the rational personality type solves problems systematically.

c. Algebraic Reasoning of Idealist Student

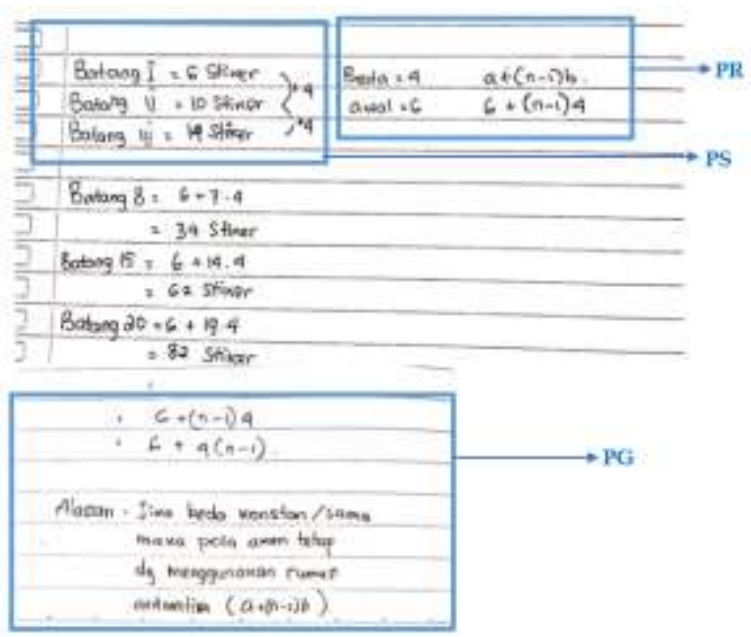

Figure 6. Idealist student's answer sheet

In pattern-seeking, IS identified the things that are known by sentence and

\begin{tabular}{|ll|}
\hline $\mathrm{R}$ & : Why did you use the \\
& arithmetic sequence \\
& formula? Are you sure that \\
& the pattern formed is \\
GS & Arithmetic sequence? \\
& : Based on pattern that has \\
& been formed by 1 ${ }^{\text {st }}$, ${ }^{\text {nd }}$, and \\
& $3^{\text {rd blocks. It can be seen that }}$ \\
each blocks has the same \\
number of different stickers. \\
It is a characteristic of \\
arithmetic sequence
\end{tabular}


diagram. In pattern recognizing, IS indicated or made the conjecture that the sequence formed is Arithmetic Sequence. To determine why IS used arithmetic sequence and found out whether IS proves the conjecture, the researcher did an interview. See the interview transcript in Figure 7.

Figure 7. Interviewed script with IS

It can be said that IS has proven the conjecture that has been made. In pattern generalization, IS made the generalization patterns by using the formula of an arithmetic sequence. The results of the interviews showed that the idealist type understands the problems he is facing. This is in line with Keirsey \& Bates (1984), who states that idealistic types tend to know the things around them.

d. Algebraic Reasoning of Artisan Student

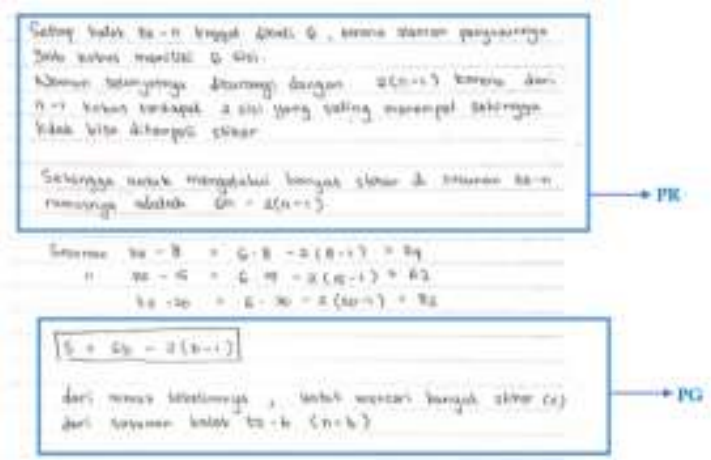

Figure 8. Artisan student's answer sheet

AS did not state what was known about the problems given, so the researcher interviewed AS to find out AS's pattern seeking process. See the interview transcript in Figure 9.

Figure 9. Interview script with AS

In pattern-seeking, AS knew the important information about the problem. But AS didn't write it. In pattern recognizing, AS made the conjecture based on the sentences and logic. But, AS did not prove the truth of the conjecture that has been made. In pattern generalization, AS generalized sticker number pattern used in the sentence RS has created. The work of the artisan shows that the artist tends to do things differently from other personality types. This is consistent with the statement of Keirsey \& Bates (1984), which states that Artisan likes

\begin{tabular}{|c|c|}
\hline $\mathrm{R}$ & $\begin{array}{l}\text { : what do you know about the } \\
\text { problems given? }\end{array}$ \\
\hline AS & $\begin{array}{l}\text { the block toy is composed of } \\
\text { several cubes. There is a sticker } \\
\text { on each side of cubes, except for } \\
\text { the sides of the cube that stick } \\
\text { each other. So the } 1^{\text {st }} \text { block } \\
\text { arrangement there are } 6 \text { stickers, } \\
\text { the } 2^{\text {st }} \text { block arrangement there } \\
\text { are } 10 \text { stickers and so on. }\end{array}$ \\
\hline $\mathrm{R}$ & $\begin{array}{l}\text { : if you were asked to write down } \\
\text { what was known, what would you } \\
\text { write? }\end{array}$ \\
\hline AS & $\begin{array}{l}\text { : nothing. Whatever is known is } \\
\text { already contained in the problem } \\
\text { given. }\end{array}$ \\
\hline
\end{tabular}

change and does not like monotony. This was following Novitasari \& Setianingsih (2019) opinion, which states that the artisan student has a flexible way to solve problems.

\section{CONCLUSION}

Based on the result and discussion discussed earlier, it is known that each personality type (Guardian, Rational, Idealist, Artisan) can solve a given problem. Each personality type solves problems in their own way and through all the indicators of algebraic reasoning. There are characteristics in each personality type in solving problems based on the logic of each research subject. Guardians and idealists solve problems with coherent procedures. Rational and Artisan solve the problem by description.

This study's implication informs that there are differences in algebraic reasoning abilities in each student's Keirsey personality type. It means that teachers have the opportunity to improve students' algebraic reasoning skills by facilitating each student based on their personality type, such as developing learning activities that can include every student's algebraic reasoning ability. 
This study focuses on how students from the high school solve math problems so that it is still possible to research to explore the algebraic reasoning abilities of students at the elementary school level to determine the development of their early algebraic reasoning abilities.

\section{REFERENCE}

Andriani, P. (2015). Penalaran Aljabar dalam Pembelajaran Matematika. Beta: Jurnal Tadris Matematika, $\quad 8(1), \quad$ 1-13. https://jurnalbeta.ac.id/index.php/bet aJTM/article/view/20

Arslan, C., Göcmencelebi, S. I., \& Tapan, M. S. (2009). Learning and reasoning styles of pre service teachers': inductive or deductive reasoning on science and mathematics related to their learning style. Procedia-Social and Behavioral Sciences, 1(1), 24602465.

https://doi.org/10.1016/j.sbspro.2009.0 $\underline{1.432}$

Aryani, F., Amin, S. M., \& Sulaiman, R. (2018, January). Students' Algebraic Reasonsing In Solving Mathematical Problems With Adversity Quotient. In Journal of Physics: Conference Series (Vol. 947, No. 1, p. 012044). IOP Publishing.

https://doi.org/10.1088/17426596/947/1/012044

Brodie. (2010). Teaching Mathematical Reasoning in Secondary School Classroom. Springer.

Dewiyani, M. J. (2009). Karakteristik Proses Berpikir Siswa Dalam Mempelajari. Prosiding Seminar Nasional Penelitian, Pendidikan Dan Penerapan MIPA, 481-492.

Herbert, K., \& Brown, R. H. (1997). Patterns As Tools. Teaching Children Mathematics, 3, 340-345.

Huitt, W. (1992). Problem solving and decision making: Consideration of individual differences using the Myers-Briggs Type Indicator. Journal of Psychological type, 24(1), 33-44. https://psycnet.apa.org/record/199445082-001

Indraswari, N. F., Budayasa, I. K., \& Ekawati, R. (2018, January). Algebraic Reasoning in Solving Mathematical Problem Based on Learning Style. In Journal of Physics: Conference Series (Vol. 947, No. 1, p. 012061). IOP Publishing. https://doi.org/10.1088/1742$\underline{6596 / 947 / 1 / 012061}$

Kasrina, \& Ode, R. (2019). Descrption of Trigonometry Problem Solving Abilities Based on Personality Type and Mathematics Learning Anxiety Levels of The Student At SMAN 6 Makassar. Daya Matematis: Jurnal Inovasi Pendidikan Matematika, 7(1), 91-101.

https://doi.org/10.26858/jds.v7i1.8849

KBBI. (2016). Kamus Besar Bahasa Indonesia (KBBI). PT Raja Grafindo.

Keirsey, D. (1998). Please Understand Me II. Prometheus Nemesis Books.

Keirsey, D., \& Bates, M. (1984). Please Understand Me. Prometheus Nemesis Books.

Kobandaha, P. E., \& Fuad, Y. (2019). Algebraic Reasoning of Students with Logical-mathematical Intelligence and Visual-spatial Intelligence in Solving Algebraic Problems. 2(4), 207-211.

https://doi.org/10.33122/ijtmer.v2i4.1 $\underline{38}$

Koruklu, N. (2015). Personality and Social Problem-Solving: The Mediating Role of Self-Esteem. Educational Sciences: Theory and Practice, 15(2), 481-487. https://doi.org/10.12738/estp.2015.2.2 $\underline{601}$

Lithner, J. (2008). A research framework for creative and imitative reasoning. Educational Studies in Mathematics, 67(3), 255-276. https://doi.org/10.1007/s10649-0079104-2

Lutfitasari, A., Amin, S. M., \& Masriyah, M. (2018). Students' Spatial Reasoning in Solving Geometrical 
Problems Based on Personality Types. In Mathematics, Informatics, Science, and Education International Conference (MISEIC 2018). Atlantis Press. https://doi.org/10.2991/miseic18.2018 .42

Masriyah, \& Firmansyah, M. H. (2018). Students' Mathematical Literacy in Solving PISA Problems Based on Keirsey Personality Theory. Journal of Physics: Conference Series, 953(1). https://doi.org/10.1088/1742$\underline{6596 / 953 / 1 / 012203}$

Mullis, I. V. . (2013). TIMSS 2015 Context Questionnaire Framework Martin. In TIMSS 2015 Assessment Frameworks. TIMSS \& PIRLS International Study Center, Lynch School of Education, Boston College and International Association for the Evaluation of Educational Achievement (IEA). http://search.ebscohost.com/login.asp $\mathrm{x}$ ?direct $=$ true $\& \mathrm{db}=$ eric $\& \mathrm{AN}=\mathrm{ED} 5452$ 50\&site $=$ ehost-live

Novitasari, Y. F., \& Setianingsih, R. (2019). Profile of Flexibility of High School Students In Mathematical Problem-Solving Based on Personality Type. Jurnal Ilmiah Pendidikan Matematika Volume, 8(3).1-10.

Solichah, S., \& Sulaiman, R. (2019). the Profile of Junior High School Students About Pisa Problem Solving Based on Personality Type. MATHEdunesa, 8(3), 465-471. https://doi.org/10.26740/mathedunesa .v8n3.p465-471

Walle, V. De, Karp, K. S., \& Bay-Williams, J. M. (2011). Elementary and Middle School Mathematics: Teaching Developmentally. Allyn \& Bacon. 